Check for updates

Cite this: RSC Adv., 2018, 8, 25133

\title{
Evaluation of disinfection by-products (DBPs) formation potential in ANAMMOX effluents $\dagger$
}

\begin{abstract}
Sike Wang, (D) Jing Fu, Hongwei Yang, Bowen Zhang, Xuchuan Shi and Jiane Zuo*
Disinfection by-products (DBPs), major health concerns in the potable reuse of municipal wastewater effluent, are process-related in wastewater treatment systems. Anammox is a promising and increasingly-applied technology for nitrogen removal in wastewater. In this study, the relationship between DBP formation potential and the anammox process has been investigated based on a lab-scale sequencing batch reactor (SBR). Excitation and emission matrix (EEM) fluorescence spectroscopy was employed to identify the compositions of the DBP precursors. The results showed that the effluents from the anammox SBR could yield both carbonaceous and nitrogenous DBPs after chlorination. Trichloromethane (TCM) was the dominant product among all DBPs detected. The anammox effluent has a low specific TCM formation potential of $0.778 \mu \mathrm{mol} / \mathrm{mmol} \mathrm{C}$ and a trichloronitromethane (TCNM) formation potential of $0.0725 \mu \mathrm{mol} / \mathrm{mmol} \mathrm{C}$, leading to a TCM and TCNM formation potential ratio of 10.7. We found that substrate utilization of anammox did not enhance DBP yields, and the DBP formation potential decreased after 10 hour starvation. High $\mathrm{pH}$ conditions stimulated the production of TCM precursors in the anammox reactor. Humic acid-like and protein-like substances were identified in the EEM spectra of anammox effluents.
\end{abstract}

Received 28th April 2018 Accepted 28th June 2018 DOI: $10.1039 / \mathrm{c} 8 \mathrm{ra03663b}$

rsc.li/rsc-advances concentrations in wastewater effluents raise health issues, becoming the major barriers in wastewater's potable reuse. A survey for eight WWTP effluents in the U.S. revealed that trihalomethane formation potentials were from 130 to $500 \mu \mathrm{g}$ $\mathrm{L}^{-1,3}$ which were far over the safety margin. Previous studies showed that DBPs and precursors presented in effluent have a tight correlation with wastewater treatment processes. It is found out that complete nitrification reduced dissolved organic matters and lowered precursor levels in WWTPs. ${ }^{2}$ Similarly, removal of organic matter benefits the reduction of DBPs formation. ${ }^{3}$ Treatment processes, especially biological ones, potentially alter the amount and contents of DBPs precursors in the effluent. These findings call for more in-depth research into the qualitative and quantitative relationship between DBPs formation and treatment processes, which is essential in DBPs control and wastewater potable reuse.

Recently, anaerobic ammonium oxidation (anammox) is being implemented as an efficient, energy-saving and sustainable alternative for traditional nitrification-denitrification processes in treating nitrogen-contained wastewater. It is believed that involvement of autotrophic anammox-based processes could benefit achieving energy-neutral WWTPs. For example, in partial nitrification-anammox (PN/A) process, ammonium oxidation bacteria oxide half of ammonium in the influent into nitrite, and then anammox bacteria convert produced nitrite and the remaining ammonium to nitrogen gas. Compared to traditional nitrification-denitrification, PN/A was reported to save $60 \%$ of aeration and $100 \%$ of organic carbon,
State Key Joint Laboratory of Environmental Simulation and Pollution Control, School of Environment, Tsinghua University, Beijing 100084, China.E-mail: wsk15@mails. tsinghua.edu.cn; fujing0520@126.com; yanghw@tsinghua.edu.cn; zbw15@mails. tsinghua.edu.cn; sxc14@mails.tsinghua.edu.cn; jiane.zuo@tsinghua.edu.cn

$\dagger$ Electronic supplementary information (ESI) available. See DOI: 10.1039/c8ra03663b 
and reduce $90 \%$ of sludge production. ${ }^{4}$ Anammox-based processes are widely applied in high-ammonium concentration wastewater, such as supernatant from anaerobic digesters in the side stream of WWTPs, and industrial waste water. ${ }^{5}$ Besides, the feasibility of implementing anammox-based processes in mainstream wastewater treatment has been explored, and significant progress has been achieved. Up to 2014, there have been over 200 full-scale anammox-involved facilities running around the world. ${ }^{6}$ Full-scale mainstream PN/A processes have also been reported. ${ }^{7,8}$ However, investigations of process-related DBPs in wastewater treatment are far from satisfactory. Only limited treatment processes, including aerated activated sludge, MBR, and anaerobic-anoxic-oxic (AAO) processes have been studied. DBPs formation potential from anammox process has never been studied before. Little information has been known concerning DBPs formation potential of anammox-treated effluent.

Therefore, the first objective of this study was to give a preliminary evaluation of DBPs formation potential of anammox-treated water. Secondly, considering DBPs precursors tightly correlate with bacterial metabolism, here we also investigated DBPs formation potential fluctuation with respect to bacterial substrate utilization and endogenous respiration phase. In the end, the impacts of $\mathrm{pH}$ condition on DBPs formation potential during anammox process were explored. To the authors' knowledge, this is the first study investigating DBPs yields from anammox process effluent.

\section{Material and methods}

\subsection{Anammox reactor operation and sampling}

A lab-scale sequencing batch reactor (SBR) was operated for more than one year. The reactor was made of polymethyl methacrylate, with a working volume of $5 \mathrm{~L}$. The reactor was automatically controlled by a programmable logic controller. The SBR cycle lasted for $100 \mathrm{~min}$ consisting of $1 \mathrm{~min}$ prestirring, 2 min feeding, $90 \mathrm{~min}$ anoxic reaction, $5 \mathrm{~min}$ settling and 2 min decanting. Pre-stirring phase aims to reduce the inhibition effect of nitrite shock loading. The volumetric exchange ratio was 0.12 resulting in a hydraulic retention time of $4.8 \mathrm{~h}$. The $\mathrm{pH}$ value was maintained between $7.3-7.8$ by adding $1 \mathrm{M} \mathrm{HCl}$. The water temperature was kept at $35 \pm 1{ }^{\circ} \mathrm{C}$ by a water bath. Impeller was installed at the bottom of the reactor with a stirring speed of $120 \mathrm{rpm}$.

The SBR was fed with synthetic wastewater based on van de Graaf et al., ${ }^{9}$ which contained: $\mathrm{NH}_{4} \mathrm{Cl} 400 \mathrm{mg} \mathrm{N} / \mathrm{L}, \mathrm{NaNO}_{2} 440 \mathrm{mg} \mathrm{N} /$ $\mathrm{L}, \mathrm{KH}_{2} \mathrm{PO}_{4} 15 \mathrm{mg} \mathrm{P} / \mathrm{L}, \mathrm{CaCl}_{2} 300 \mathrm{mg} \mathrm{L}{ }^{-1}, \mathrm{MgSO}_{4} \cdot 7 \mathrm{H}_{2} \mathrm{O} 200 \mathrm{mg} \mathrm{L}^{-1}$, $\mathrm{NaHCO}_{3} 400-800 \mathrm{mg} \mathrm{L}^{-1}, 1.22 \mathrm{~mL} \mathrm{~L}^{-1}$ of trace element solution (I) and $1.22 \mathrm{~mL} \mathrm{~L}^{-1}$ of trace element solution (II). The trace element solution (I) contained $\mathrm{FeSO}_{4} \cdot 7 \mathrm{H}_{2} \mathrm{O} 7.5 \mathrm{~g} \mathrm{~L}^{-1}$, EDTA $5 \mathrm{~g} \mathrm{~L}^{-1}$. The trace element solution (II) consisted of: EDTA $15 \mathrm{~g} \mathrm{~L}^{-1}, \mathrm{CuSO}_{4} \cdot 5 \mathrm{H}_{2} \mathrm{O}$ $0.22 \mathrm{~g} \mathrm{~L}^{-1}, \mathrm{ZnSO}_{4} \cdot 7 \mathrm{H}_{2} \mathrm{O} 0.43 \mathrm{~g} \mathrm{~L}^{-1}, \mathrm{NiCl}_{2} \cdot 6 \mathrm{H}_{2} \mathrm{O} 0.19 \mathrm{~g} \mathrm{~L}^{-1}, \mathrm{Na}_{2}-$ $\mathrm{SeO}_{4} \cdot 10 \mathrm{H}_{2} \mathrm{O} 0.21 \mathrm{~g} \mathrm{~L}^{-1}, \mathrm{Na}_{2} \mathrm{MoO}_{4} \cdot 2 \mathrm{H}_{2} \mathrm{O} 0.22 \mathrm{~g} \mathrm{~L}^{-1}, \mathrm{H}_{3} \mathrm{BO}_{3} 0.014 \mathrm{~g}$ $\mathrm{L}^{-1}, \mathrm{MnCl}_{2} \cdot 4 \mathrm{H}_{2} \mathrm{O} 0.99 \mathrm{~g} \mathrm{~L}^{-1}$.

SBR effluent samples were collected daily for eight days to characterize DBPs formation potential. All water samples were immediately filtered through $0.45 \mu \mathrm{m}$ pore size filters and stored at $4{ }^{\circ} \mathrm{C}$ for further analysis of dissolved organic carbon (DOC), EEM fluorescence, and DBP formation potential (DBPFP) tests.

\subsection{Batch tests}

To further explore DBPFP's change during bacterial substrate utilization, batch tests were conducted in this study. Batch experiments were carried out in the same SBR after the decanting phase. The sludge in the reactor was washed three times to remove residual substrate and dissolved organic matters. To minimize disturbance posed on microorganisms, fresh mineral medium (no nitrite and ammonium addition) as described in 2.1 was used. After filling the reactor to $5 \mathrm{~L}$ with the same mineral medium, the supernatant was collected in triplicates to test the remaining dissolved organics and its DBPFP. A concentrated solution $(10 \mathrm{~mL})$ containing substrate was then added to the reactor to achieve final concentrations of $50 \mathrm{mg} \mathrm{N} /$ $\mathrm{L}$ for nitrite and ammonium, respectively. After 1 min's homogenization, water samples were taken in triplicates representing the start of batch tests. The mixed liquid samples were taken periodically from a sampling port of the reactor. After settling down for $3 \mathrm{~min}$, the supernatant was filtrated through $0.45 \mu \mathrm{m}$ pore size membrane filters and kept in $4{ }^{\circ} \mathrm{C}$ until further analysis of DOC, EEM fluorescence and DBPFP tests.

During batch tests, nitrite and ammonium concentrations were varied from 0 to $40 \mathrm{mg} \mathrm{N} / \mathrm{L}$. It was reported that nitrite could enhance halonitromethanes formation in chlorination tests of humic acid and water samples from a drinking water treatment plant. ${ }^{10}$ Thus, to figure out the effect of nitrite and ammonium on DBP formation, additional effluent samples were taken during the normal operation of the SBR. Samples were spiked with serial nitrite and ammonium concentrations $(0,2,10$ and $40 \mathrm{mg} \mathrm{N} / \mathrm{L})$, and then they were subjected to DBP formation potential tests.

\section{3 pH tests}

$\mathrm{pH}$ tests were performed to figure out the impact of $\mathrm{pH}$ conditions on DBP formation potential. At the beginning of SBR cycle, $\mathrm{pH}$ values of bulk liquid were adjusted to 8.0, 7.7 and 7.0 respectively by adding $1 \mathrm{M} \mathrm{HCl}$ or $1 \mathrm{M} \mathrm{NaOH}$. The $\mathrm{pH}$ values were manually maintained by adding $1 \mathrm{M} \mathrm{HCl}$ during the whole cycle. An online $\mathrm{pH}$ probe (SenTix 950, WTW) was used to monitor $\mathrm{pH}$ values of the reactor. Effluents were sampled, filtered and stored for further analysis. Three recovery SBR cycles were conducted between each pH values.

\subsection{DBP formation potential (DBPFP) tests}

DBP formation potential tests were conducted to evaluate the maximum DBP formation ability of the water samples. Free chlorine was used as the disinfectant in DBPFP tests. The oxidation of ammonium in the effluents by chlorine will generate chloramine, which would affect DBPs formation. Thus, excessive chlorine is needed in DBPFP tests to prevent chloramination. Pre-chlorine dosing experiments were carried out to evaluate chlorine demand of samples. Finally, a chlorine 
dosage of $\left(3 \times\right.$ TOC $\left.+5 \times \mathrm{NO}_{2}{ }^{-}+8 \times \mathrm{NH}_{4}{ }^{+}+30\right) \mathrm{mg} \mathrm{Cl}_{2} / \mathrm{L}$ was used, which ensured that residual chlorine in samples was higher than $10 \mathrm{mg} \mathrm{Cl}_{2} / \mathrm{L}$. Triple $40 \mathrm{ml}$ samples were chlorinated with stock $\mathrm{NaOCl}$ solution and incubated in the dark for 3 days at $\mathrm{pH}$ 7.0. After 3 days incubation, the residual chlorine was quenched with $\mathrm{NH}_{4} \mathrm{Cl}$, and the formed DBPs was measured immediately. The chlorine concentration of stock NaOCl solution and residual chlorine were measured by DPD free chlorine reagent powder pillows (Hach Company).

In this study, chlorination DBPs were determined by liquidliquid extraction based on EPA Method 551.1. ${ }^{11}$ Water samples $\left(40 \mathrm{~mL}\right.$ ) were extracted with $3 \mathrm{~mL}$ MTBE (containing $1000 \mu \mathrm{g} \mathrm{L}^{-1}$ of bromofluorobenzene and 1,2-dibromopropane) and $11 \mathrm{~g}$ of anhydrous sodium sulfate. Trichloronitromethane (TCNM) was analyzed by a gas chromatography (GC, Agilent 7890B, Santa Clara, USA) equipped with a DB-5 MS UI capillary column $(30 \mathrm{~m}$ $\times 0.25 \mathrm{~mm} \times 0.25 \mu \mathrm{m}$, Agilent, USA) and a mass spectrometer (MS, Agilent 5977A, Santa Clara, USA). After the analysis of TCNM, other DBPs were measured by a GC (Agilent 7890A, Santa Clara, USA $)$ with a DB-1 capillary column $(30 \mathrm{~m} \times 0.25 \mathrm{~mm}$ $\times 0.25 \mu \mathrm{m}$, Agilent, USA) and an electron capture detector. Only trichloromethane (TCM), chloral hydrate (CH), TCNM and dichloroacenitrile (DCAN) data is presented in this paper. Other DBPs were below detection limits.

\subsection{Analytical method}

The dissolved organic matters were measured as dissolved organic carbon (DOC) using the non-purgeable organic carbon analysis by a TOC analyzer (TOC-L, Shimadzu, Japan).

Samples were subjected to EEM measurement without dilution. The fluorescence spectroscopy was obtained by a fluorescence spectrophotometer (F-7000, Hitachi, Japan). For all measurements, excitation wavelengths start from 220 to $500 \mathrm{~nm}$ on $5 \mathrm{~nm}$ step and emission wavelengths are from 230 to $650 \mathrm{~nm}$ on $5 \mathrm{~nm}$ step. Excitation and emission slits were set to $5 \mathrm{~nm}$ and the photomultiplier tube (PMT) voltages used were $700 \mathrm{~V}$. To correct inner filter effects, the absorbance of samples was recorded from 220 to $650 \mathrm{~nm}$ with $0.5 \mathrm{~nm}$ step in a $1 \mathrm{~cm}$ quartz cuvette (DR6000, Hach, USA). The samples' fluorescence data was subjected to inner filter correction. And then Raman normalization was performed using Raman scatter peak obtained from a Milli-Q water sample as reference. Finally, the Raman signal was removed by subtracting blank sample (Milli$\mathrm{Q}$ water) EEM. These procedures transformed fluorescence intensity into Raman units (R.U.). The drEEM toolbox was employed to perform these procedures for EEM data. ${ }^{\mathbf{1 2}}$

$\mathrm{UV}_{254}$ was determined by a UV-visible spectrophotometer (DR6000, Hach, USA) with a $1 \mathrm{~cm}$ quartz cuvette. $\mathrm{NO}_{2}{ }^{-}, \mathrm{NH}_{4}{ }^{+}$, $\mathrm{NO}_{2}{ }^{-}$were analyzed according to Standard Method. ${ }^{13}$

\section{$2.6 \mathrm{QA} / \mathrm{QC}$}

Batch tests were conducted in parallel three times. Chlorination of DBPFP analysis was conducted in triplicate to assure analysis quality. Synthetic influent for the reactor was used as background DBPs value. The detection limit for TCNM was $0.06 \mu \mathrm{g} \mathrm{L}^{-1}$, and it was $0.10 \mu \mathrm{g} \mathrm{L}^{-1}$ for other DBPs.

\section{Results and discussion}

\subsection{DBPs formation of anammox effluent}

The average water quality parameters of the daily anammox SBR effluents are presented in Table 1 and more detailed daily data could be seen in Fig. S1. $\uparrow$ To avoid nitrite inhibition on anammox bacteria, more ammonium was added in the synthetic wastewater, where the ratio of nitrite and ammonium was 1.2, lower than the theoretical ratio 1.32. Hence excess ammonium was left in the effluent. The effluent nitrite was kept below $3 \mathrm{mg}$ $\mathrm{N} / \mathrm{L}$ and the average volumetric nitrogen removal rate was 0.89 $\pm 0.19 \mathrm{~kg} \mathrm{~N} / \mathrm{m}^{3} \mathrm{~d}$, indicating a stable and excellent performance of the anammox SBR.

After chlorination, both carbonaceous and nitrogenous disinfection byproducts (C-DBPs, N-DBPs) were detected, as shown in Fig. 1. As there was no bromide addition in the influent, brominated DBPs were all under detection limits. Generally, individual DBPs yield in the effluent was ranked as follows: TCM $>\mathrm{CH}>$ TCNM $>$ DCAN. TCM was the predominant species during sampling days. Concentrations of TCM varied in the range of $0.394-0.597 \mu \mathrm{mol} \mathrm{L}^{-1}$ and accounted for 75.7-83.7\% DBPs formation in the effluent. For N-DBPs detected, the generation of DCAN was trace, which had an average yield of $0.007 \mu \mathrm{mol} \mathrm{L}{ }^{-1}$. TCNM varied from $0.016 \mu \mathrm{mol}$ $\mathrm{L}^{-1}$ to $0.054 \mu \mathrm{mol} \mathrm{L}^{-1}$, accounting for $2.3-10.4 \%$ DBPs formation in the effluent. The highest DBP yield was observed on day 1 , while the highest specific DBP yield occurred on day 3. In the correlation analysis, DOC showed a weak and positive correlation with TCM and $\mathrm{CH}$ concentrations (correlation coefficient $<0.5)$. Specific ultraviolet absorbance $\left(\mathrm{SUV}_{254}\right)$, the ratio of $\mathrm{UV}_{254}$ and DOC, is often applied in DBPs formation assessment. ${ }^{14}$ Correlation coefficients between $\mathrm{SUV}_{254}$ and TCM/DOC, CH/DOC, TCNM/DOC were $0.63,0.66$ and 0.85 . This positive correlation suggested that UV-absorbed organic matters were substantial DBPs precursors.

The average specific TCM yield in the anammox effluent was $0.778 \mu \mathrm{mol} / \mathrm{mmol}$ DOC, and the average specific TCNM yield per DOC was $0.072 \mu \mathrm{mol} / \mathrm{mmol}$ DOC (Table 2). Considering other wastewater treatment processes, Meng et al. examined the DBP formation of MBR and AAO process. In the lab-scale MBR system, TCM yield was as high as $50 \mu \mathrm{mol} / \mathrm{mmol}$ DOC and TCNM was $0.912 \mu \mathrm{mol} / \mathrm{mmol}$ DOC. For AAO process, the specific TCM yield was 5.7 and TCNM was $0.22 \mu \mathrm{mol} / \mathrm{mmol}$ DOC. ${ }^{15}$ In an aerated activated sludge system, it was reported that specific DBP yield in the effluent was $4.196 \mu \mathrm{mol} / \mathrm{mmol}$ DOC for TCM and $0.0032 \mu \mathrm{mol} / \mathrm{mmol}$ DOC for TCNM. ${ }^{16}$ The average TCM yield per DOC of anammox effluent is obviously less than these studies, reflecting an inferior ability of organic substances in anammox effluent to generate TCM after chlorination. Meanwhile, TCNM and DCAN yield of anammox

Table 1 Average water quality parameters of anammox SBR effluent

\begin{tabular}{|c|c|c|c|c|}
\hline $\begin{array}{l}\mathrm{NO}_{2}{ }^{-}-\mathrm{N} \\
(\mathrm{mg} \mathrm{N} / \mathrm{L})\end{array}$ & $\begin{array}{l}\mathrm{NH}_{4}{ }^{+}-\mathrm{N} \\
(\mathrm{mg} \mathrm{N} / \mathrm{L})\end{array}$ & $\begin{array}{l}\mathrm{NO}_{3}{ }^{-}-\mathrm{N} \\
(\mathrm{mg} \mathrm{N} / \mathrm{L})\end{array}$ & $\begin{array}{l}\text { DOC } \\
\left(\mathrm{mg} \mathrm{L}^{-1}\right)\end{array}$ & $\begin{array}{l}\mathrm{UV}_{254} \\
\left(\mathrm{~cm}^{-1}\right)\end{array}$ \\
\hline
\end{tabular}

$2.00 \pm 0.34 \quad 9.64 \pm 4.54 \quad 30.23 \pm 8.67 \quad 7.85 \pm 2.54 \quad 0.14 \pm 0.028$ 

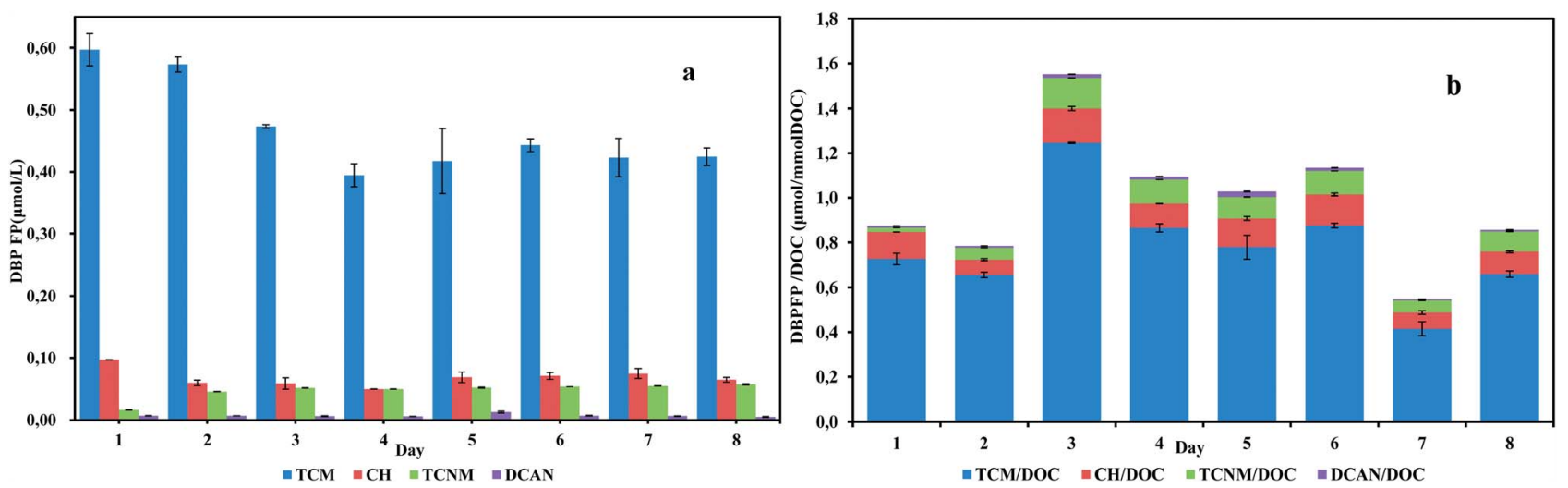

Fig. 1 DBP yields (a) and specific DBP yields (b) of daily anammox SBR effluents exposed to chlorine.

effluent are comparable to previous studies, exhibiting similar high-toxic N-DBP generation ability. The anammox effluents had a lower TCM to TCNM formation potential ratio (10.7) compared with other processes. The DBPFP analysis results from this study unravel that the anammox effluent features in weaker TCM formation ability and similar N-DBPs formation potential compared with the previously studied processes.

In this study, there was no organics addition in the influent. Thus, the organics in the effluent were attributed to microbialorigin products, e.g., extracellular polymeric substances, residual inert material, and soluble microbial products (SMP). ${ }^{17}$ These microbial products are proved to facilitate DBPs formation during chlorination. ${ }^{16,18}$ DBPs formation results inferred that microbial products in anammox effluent contained less TCM precursors. Meanwhile, organic matters inducing N-DBPs were a significant part of microbial products in anammox effluent. For DCAN, these organic precursors could be free amino acids, nucleic acid, proteinaceous matters and combined amino acids bound to humic structures. TCNM could be originated from nitrogencontained organic matters and humic acids. ${ }^{19}$ The results in this study indicate that the anammox process would not lead to great TCM formation potential in the WWTPs effluent, while N-DBPs formation needs further assessment in anammox effluent.

\subsection{DBPFP evolution during substrate utilization and endogenous respiration}

In autotrophic anammox system, organic matters in the effluent are originated from bacterial metabolism, which is associated with substrate availability. With abundant substrate, organic matters are concomitantly produced from substrate metabolism. ${ }^{20}$ During starvation, the microbial community lacks the energy source to catalyze organics. To elucidate DBP precursors' evolution during substrate utilization and to figure out DBPFP trending in the absence of substrate, batch tests were conducted. The profiles of nitrite, ammonium, and nitrate during the batch tests are shown in Fig. S2. $\dagger$ In batch tests, nitrite was consumed within $150 \mathrm{~min}$. The ratio of nitrite and ammonium removed was 1.37 and the nitrate production versus ammonium consumption was 0.21 , which were slightly different from the previously reported stoichiometry of anammox process. ${ }^{21}$ Steady anammox activity was achieved.

As nitrite has been reported to enhance the generation of TCNM at a concentration of $2 \mathrm{mg} \mathrm{N} / \mathrm{L},{ }^{22}$ control experiments have been done to exclude the effects of nitrite and ammonium on DBP generation (Fig. S3 and S4†). Similar DBPs generation was observed within the range of $0-40 \mathrm{mg} \mathrm{N} / \mathrm{L}$ for both nitrite and ammonium. By correlation analysis, the correlation coefficient was -0.27 for nitrite and TCM, 0.2 for ammonium and TCM, which suggested that nitrite and ammonium concentration would not have a noticeable influence on DBP formation in anammox effluent.

The evolution of DBP yield in batch tests is presented in Fig. 2. Before the start of the experiment, the sludge had been washed three times trying to remove the existing organic precursors (loosely bounded extracellular polymeric substances, soluble microbial products, et al.). It turned out that there were still considerable precursors presenting in the bulk liquid. The sum of DBPFP detected in the supernatant after

Table 2 Specific DBP yield of anammox SBR effluents and comparison with other processes

Specific DBPFP $(\mu \mathrm{mol} / \mathrm{mmol} \mathrm{C})$

\begin{tabular}{|c|c|c|c|c|c|c|}
\hline \multirow[b]{2}{*}{ Process } & & \multirow{2}{*}{$\begin{array}{l}\text { Disinfectant/incubation } \\
\text { time }\end{array}$} & \multirow[b]{2}{*}{ Source } \\
\hline & TCM & TCNM & DCAN & TCM/TCNM & & \\
\hline Anammox & 0.778 & 0.0725 & 0.0109 & 10.7 & Chlorine, 3 days & This study \\
\hline MBR & 50.25 & 0.91 & 3.54 & 54 & Chlorine, 7 days & 15 \\
\hline AAO & 5.02 & 0.22 & 0.54 & 22 & Chlorine, 7 days & 15 \\
\hline Aerated activated sludge & 4.19 & 0.0032 & 0.0133 & 1250 & Chlorine, 7 days & 16 \\
\hline
\end{tabular}



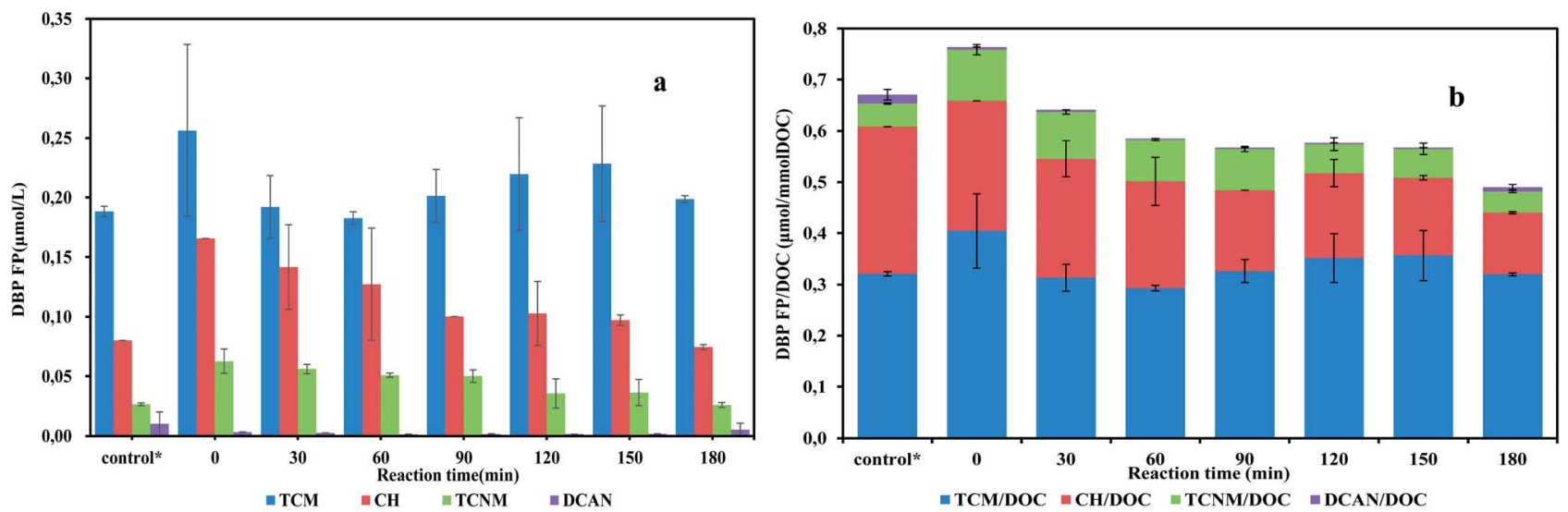

Fig. 2 DBP yields (a) and specific DBP yields (b) of batch tests samples exposed to chlorine. *The control group represents the DBPs yield of the supernatant after sludge washing.

sludge washing was up to $0.292 \mu \mathrm{mol} \mathrm{L}{ }^{-1}$. In the batch test, the highest DBP yield was detected at the moment right after the addition of substrate, which was up to $0.792 \pm 0.22 \mu \mathrm{mol} \mathrm{L}^{-1}$. This instant increasing of DBPFP may be attributed to the immediate excrement of soluble microbial products due to substrate addition. It is believed that the addition of substrate would stimulate SMP generation, ${ }^{17}$ which would definitely boost DBPFP. Although the instant enhancement of DBPFP in the addition of substrate was unwanted, this production could be decreased in subsequent substrate utilization phase (Fig. 2).

When there are sufficient nitrite and ammonium in bulk liquid, anammox bacteria take up nitrite and ammonium to generate energy for maintaining cells activities. During the substrate utilization phase, which was the first $150 \mathrm{~min}$ in this study (Fig. S2 $\dagger$ ), the sum of DBPFP detected varied from 0.352 to $0.392 \mu \mathrm{mol} \mathrm{L}^{-1}$. No apparent ascending trend, either DBPFP or TOC concentration, was observed. Results were opposed to the hypothesis. In contrast to this study, a giant increase of DBP yield was observed during substrate utilization in a previous study, where aerated activated sludge was supplied with organic carbon. ${ }^{23}$ Also, it has been reported that anammox SMP concentrations increased slowly during substrate metabolism phase. ${ }^{24}$ This difference might be introduced by various compositions of microbial communities. For individual DBP species, TCM started to rise after 1 hour, while CH and TCNM formation potential showed decreasing trend in the batch test. Total DBPFP did not increase significantly during substrate utilization in this study, which means anammox was a low DBP risk process.

In the endogenous respiration phase, which was after $150 \mathrm{~min}$ in batch tests, nitrite and ammonium were running out. A slight decrease was observed in DBPFP in this phase. However, the trend was not clear. To further confirm the reduction during the endogenous phase, an extended endogenous period was applied to the anammox SBR. At the end of an SBR cycle, the reactor kept stirring without feeding and decanting phase for ten hours. Then the solution was sampled to test the effects of endogenous respiration. Results (Table S1 $\dagger$ ) showed that after 10 hours' endogenous respiration, the DOC concentration decreased slightly compared with substrate utilization phase. For DBP formation, specific CH, TCNM and DCAN yields were much lower than substrate utilization phase, and TCM had similar specific yield. Precursors of TCNM and DCAN mainly consist of organic nitrogen-contained substances. TCM originated from a wide range of organics, including proteins, polysaccharides, humic acid and other carboncontained substances. During endogenous respiration period, organics anabolism from anammox bacteria declines enormously due to the shortage of nitrite and ammonium. While biodegradable organic precursors, like proteins, keep being consumed by heterotrophic bacteria inhabiting the microbial community, leading to the decrease of organic precursors in the effluent. Consequently, DBPFP reduced. Similarly, it has also been reported that less soluble microbial products were measured when sludge was under starvation. ${ }^{25}$

In this autotrophic system, anammox bacteria were acted as energy supporter for heterotrophic groups. During substrate utilization phase, anammox activity was ongoing and microbial organic compounds, the potential DBPs precursors, were produced at the same time. Some of them would be released in liquid phase. In the meantime, heterotrophs in the community would scavenge the organics in bulk liquid, ${ }^{24}$ which might be the reason why no DBPFP increasing was observed in substrate utilization phase. In endogenous phase, the substrate support was shut down so the whole community could only live on residue organics and biomass decay, which led to less organic matters left in the effluent. In this study, this could explain the decrease of DBPFP after endogenous phase. The DBP formation potential in the anammox effluent relies on the organic matters mass balance impacted by bacteria community.

\subsection{Effects of $\mathrm{pH}$ values on DBPFP}

Anammox activity is strongly affected by $\mathrm{pH}$ values. The optimal $\mathrm{pH}$ range for anammox growth and activity was reported to be 6.7-8.3. ${ }^{26}$ During the operation of actual anammox project, fluctuant $\mathrm{pH}$ condition is not avoidable. To evaluate the effects of given $\mathrm{pH}$ values on the generation of DBP precursors, $\mathrm{pH}$ tests were conducted. The effluent quality results are shown in 

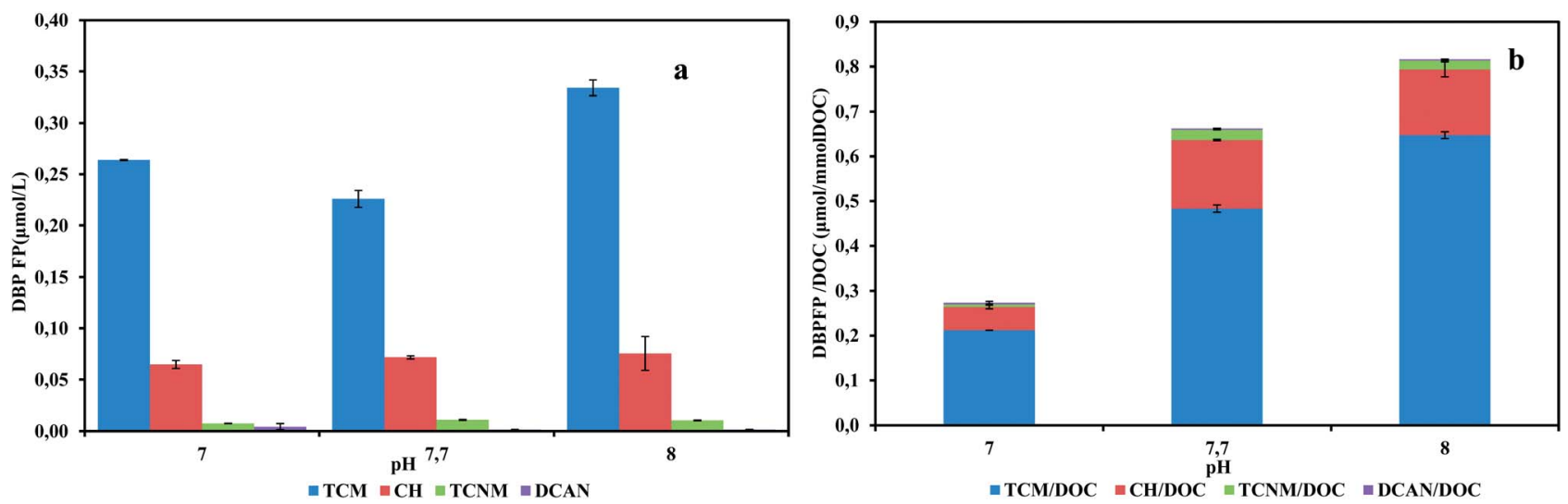

Fig. 3 DBP yields (a) and specific DBP yields (b) of effluents from different $\mathrm{pH}$.

Table S2. $\dagger$ The effluent nitrite concentrations were below $1 \mathrm{mg}$ $\mathrm{N} / \mathrm{L}$ in all $\mathrm{pH}$ values, showing that tested $\mathrm{pH}$ range did not inhibit anammox activities. The excellent anammox performances were achieved in $\mathrm{pH}$ tests. Total specific DBPFP were $0.27,0.66,0.81 \mu \mathrm{mol} / \mathrm{mmol}$ DOC for $\mathrm{pH} 7.0,7.7,8.0$, respectively (Fig. 3). Highest specific DBP yield occurred in $\mathrm{pH} 8$ while highest DOC concentration was in $\mathrm{pH} 7$.

The anammox SBR usually ran between $\mathrm{pH}$ 7.3-7.8, which meant the microbial community had adapted to this $\mathrm{pH}$ range. The increased DOC concentration in pH 7 effluent could be a result of the bacteria reaction against this abnormal $\mathrm{pH}$ value. It has been recorded that more soluble microbial products was excreted to adjust to stressful environment. ${ }^{17}$ But the increased DOC in pH 7 did not hold more DBP precursors. Another study showed that $\mathrm{pH}=4$ greatly enhanced the production of hydrophobic humic acid-like organics in aerated activated sludge system, which were potential DBP precursors. ${ }^{25}$

When investigating DBPFP in process effluent, $\mathrm{pH}$ values should be considered due to its fluctuation and it could affect the generation of microbial products greatly. In this study, three different $\mathrm{pH}$ values were applied in anammox SBR and resulted in various DOC. This difference was caused by changes of microbial products in given $\mathrm{pH}$ environment. Also, the DBP yield per DOC was increased with $\mathrm{pH}$, which indicated the shift of precursor's compositions. $\mathrm{pH}$ values could affect DBPFP in the effluent, but the mechanisms underneath this need further study.

\subsection{EEM fluorescence spectroscopy}

EEM fluorescence spectroscopy, which is a convenient and fast method for water quality assessment, has broad application in DBP precursor's research. In this study, all water samples were subjected to EEM fluorescence analysis. The representative EEM profiles of anammox SBR effluents and the batch tests samples $(t=30,180 \mathrm{~min})$ were shown in Fig. 4. Four fluorescence peaks could be picked in most samples. Peak 1 features in emission wavelength of $460 \mathrm{~nm}$ and excitation wavelength of $250 \mathrm{~nm}$. According to five EEM regions classified by Chen et al., Peak 1 located in Region V, humic acid-like area. ${ }^{27}$ Peak 2 with emission wavelength of $460 \mathrm{~nm}$ and excitation wavelength of $400 \mathrm{~nm}$ is also identified as humic acid-like substances. Peak $3\left(E_{\mathrm{x}} / E_{\mathrm{m}}=275 / 305\right)$ located in Region IV, where soluble microbial by-product-like compounds including tyrosine-, tryptophan-, and protein-like substances prevail. Peak $4\left(E_{\mathrm{x}} / E_{\mathrm{m}}=230 / 305\right)$ lies in Region I, representing aromatic proteins.

After normalization, the fluorescence intensities of these four peaks were converted to Raman units to eliminate deviation caused by machines. The correlation coefficient of Peak 1 and Peak 2 intensity was 0.999 (data not shown). High correlation coefficient and almost the same emission wavelength of Peak 1 and Peak 2 strongly imply that the two fluorophores might originate from the same substance. Similarly, a humic acid-like component $\left(E_{\mathrm{x}} / E_{\mathrm{m}}=275,420 / 460\right)$ was identified in anammox-based process effluent. ${ }^{28}$ The intensities of daily anammox effluents ranged from 0.82-2.65 R.U. for Peak 1 and 0.028-0.90 R.U. for Peak 2. The correlation analysis exhibits that correlation coefficient between TCM concentration and fluorescence intensities (Peak 1 and Peak 2) was 0.87, indicating the strong positive correlation between TCM and humic acid-like peak intensities. It has also been reported that TCM formation strongly was linked to humic acid-like components. ${ }^{14}$ This correlation indicates that the humic acid-like fluorophores play an essential role in DBP formation and could be used as a proxy for TCM precursors. However, the intensities of Peak 3 and Peak 4, identified as protein-like substances, were weak in anammox SBR effluent.

Fluorescence intensities profile during batch tests is shown in Fig. 5. Peak 1 and Peak 2 could hardly be detected in the beginning and then kept increasing during the whole batch tests, indicating humic acid-like matters accumulated during the entire substrate utilization phase and starvation phase. Humic acid-like matters are believed to be hard-biodegradable so they are likely to remain in the effluents. ${ }^{29,30}$ While Peak 3 and Peak 4 initially raised and then decreased over time. Peak 3 and Peak 4 were identified as protein-like substances, which could be consumed by heterotrophic bacteria. Correlation analysis showed that a low correlation coefficient (0.38) was drawn from Peak 3 intensity and TCM concentration. Other peaks (Peak 1, Peak 2 and Peak 4) did not show a relation with TCM generation, which was not constant with results drawn from anammox SBR effluent. In the case of $\mathrm{CH}$, Peak 3 

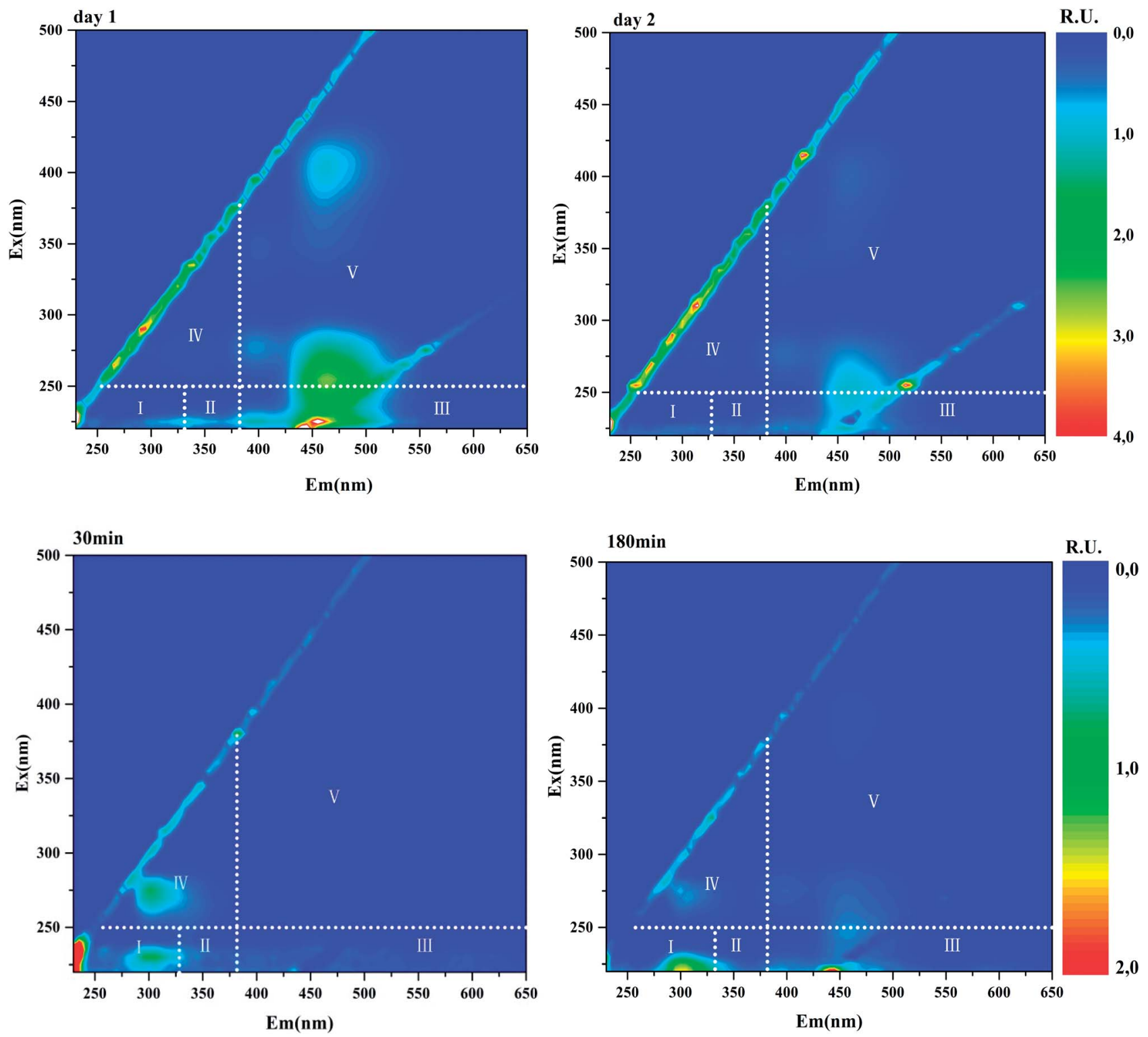

Fig. 4 Representative EEM profiles of daily anammox SBR effluents (upper row) and batch tests samples (lower row). The fluorescence intensities were normalised to Raman units (R.U.).

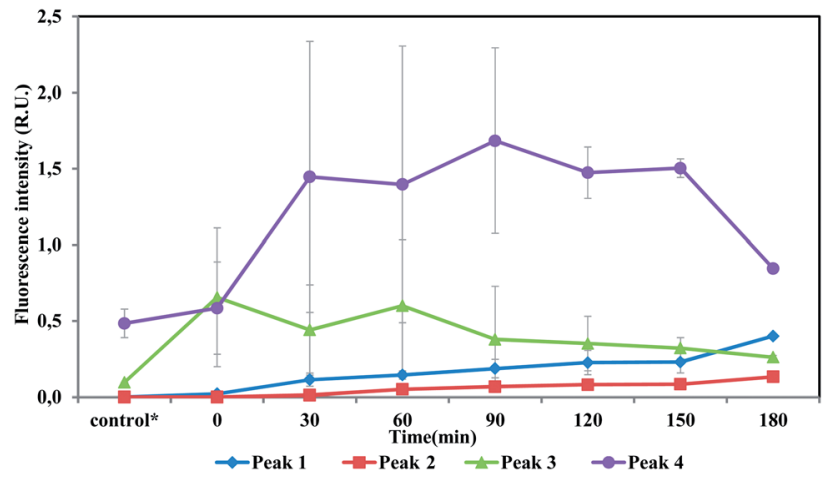

Fig. 5 Intensities profile of four fluorescence peaks during batch tests. *The control group represents the fluorescence intensity of the supernatant after sludge washing. positively correlated with $\mathrm{CH}(0.87)$, while other peaks showed no relationship with $\mathrm{CH}$. For N-DBP groups, the correlation coefficient was 0.88 between Peak 3 and TCNM yield, showing relatively strong correlation. A low correlation coefficient (0.22) was found between TCNM and Peak 4. DCAN showed no relation with all fluorophores, which might be explained by low concentrations of DCAN. In batch tests, Peak 3, identified as protein-like substances, positively correlated with DBPs formation, which indicated that proteinaceous compounds were important DBPs precursors.

\section{Conclusions}

This study firstly unravels the DBPFP of effluents from an anammox-dominated reactor. The effluents from a lab-scale anammox SBR exhibited lower TCM formation potential 
compared with MBR, AAO and aerated activated sludge process, while TCNM formation potential was comparable. Results from batch tests suggested that DBP yields were barely raised by substrate utilization. Higher DBPFP was measured at pH 8. EEM showed that humic acid-like substances positively correlated with TCM generation. In anammox process, higher $\mathrm{pH}$ needs to be avoided in practical application, preventing the enhancement of DBP formation potential. EEM analysis and UV absorbance could provide a glimpse into organic precursors in effluents. Further studies are called to explore more detailed compositions of organic matters serving as precursors and quantify their contribution to DBP formation.

\section{Conflicts of interest}

There are no conflicts to declare.

\section{Abbreviations}

$\begin{array}{ll}\text { AAO } & \text { Anaerobic-anoxic-oxic } \\ \text { Anammox } & \text { Anaerobic ammonium oxidation } \\ \text { C-DBPs } & \text { Carbonaceous disinfection byproducts } \\ \text { CH } & \text { Chloral hydrate } \\ \text { DBPs } & \text { Disinfection by-products } \\ \text { DBP } & \text { Disinfection by-product } \\ \text { DBPFP } & \text { Disinfection by-product formation potential } \\ \text { DOC } & \text { Dissolved organic carbon } \\ \text { DCAN } & \text { Dichloroacenitrile } \\ \text { EEM } & \text { Excitation and emission matrix } \\ \text { FP } & \text { Formation potential } \\ \text { N-DBPs } & \text { Nitrogenous disinfection byproducts } \\ \text { PN/A } & \text { Partial nitrification-anammox } \\ \text { R.U. } & \text { Raman units } \\ \text { SBR } & \text { Sequencing batch reactor } \\ \text { SMP } & \text { Soluble microbial products } \\ \text { SUVA } & \text { Specific ultraviolet absorbance } \\ \text { TCM } & \text { Trichloromethane } \\ \text { TCNM } & \text { Trichloronitromethane } \\ \text { UV } & \text { Ultraviolet absorbance at } 254 \text { nm } \\ \text { WWTPs } & \text { Wastewater treatment plants }\end{array}$

\section{Acknowledgements}

The work was funded by National Natural Science Foundation of China (Project No. 21677084).

\section{References}

1 USEPA, Fed. Regist., 2006, vol. 71, pp. 387-493.

2 S. W. Krasner, P. Westerhoff, B. Chen, G. L. Amy, S.-N. Nam, Z. K. Chowdhury, S. Sinha and B. E. Rittmann, Contribution of Wastewater to DBP Formation, Awwa Research Foundation, Denver, 2008.
3 H. L. Tang, Y.-C. Chen, J. M. Regan and Y. F. Xie, J. Environ. Monit., 2012, 14, 1515-1522.

4 G. T. Daigger, Water Environ. Res., 2014, 86, 204-209.

5 K. Isaka, Y. Kimura, M. Matsuura, T. Osaka and S. Tsuneda, Biochem. Eng. J., 2017, 122, 115-122.

6 S. Lackner, E. M. Gilbert, S. E. Vlaeminck, A. Joss, H. Horn and M. C. M. van Loosdrecht, Water Res., 2014, 55, 292-303.

7 G. T. Daigger, G. A. Nicholson, C. K. Lee Yih, M. W. Hee, Y. J. Chye, Y. A. Ghani and Y. W. Hin, Proc.-Water Environ. Fed., 2008, 2008, 311-330.

8 B. Wett, A. Omari, S. M. Podmirseg, M. Han, O. Akintayo, M. Gómez Brandón, S. Murthy, C. Bott, M. Hell, I. Takács, G. Nyhuis and M. O'Shaughnessy, Water Sci. Technol., 2013, 68, 283-289.

9 A. a. Van De Graaf, P. De Bruijn, L. a. Robertson, M. S. M. Jetten and J. G. Kuenen, Microbiology, 1996, 142, 2187-2196.

10 J. Hu, H. Song and T. Karanfil, Environ. Sci. Technol., 2010, 44, 794-799.

11 D. Munch and D. Hautman, J. Environ. Prot., 1995, 1-61.

12 K. R. Murphy, C. A. Stedmon, D. Graeber and R. Bro, Anal. Methods, 2013, 5, 6557.

13 APHA, Stand. Methods, 2005, p. 541.

14 A. D. Pifer and J. L. Fairey, Water Res., 2012, 46, 2927-2936. 15 Y. Meng, M. Wang, B. Guo, F. Zhu, Y. Wang, J. Lu, D. Ma, Y. Sun and B. Gao, Chem. Eng. J., 2017, 315, 243-250.

16 B. Zhang, Q. Xian, J. Zhu, A. Li and T. Gong, Chem. Eng. J., 2015, 279, 258-263.

17 D. J. Barker and D. C. Stuckey, Water Res., 1999, 33, 30633082 .

18 Z. Wang, O. Choi and Y. Seo, Environ. Sci. Technol., 2013, 47, 9764-9773.

19 W. Lee, P. Westerhoff and J.-P. Croué, Environ. Sci. Technol., 2007, 41, 5485-5490.

20 C. Kunacheva and D. C. Stuckey, Water Res., 2014, 61, 1-18.

21 M. Strous, J. J. Heijnen, J. G. Kuenen and M. S. M. Jetten, Appl. Microbiol. Biotechnol., 1998, 50, 589-596.

22 J. Shan, J. Hu, S. Sule Kaplan-Bekaroglu, H. Song and T. Karanfil, Chemosphere, 2012, 86, 323-328.

23 J. lin Liu, X. yan Li, Y. feng Xie and H. Tang, Sci. Total Environ., 2014, 472, 818-824.

24 B. J. Ni, M. Ruscalleda and B. F. Smets, Water Res., 2012, 46, 4645-4652.

25 Z. P. Wang and T. Zhang, Water Res., 2010, 44, 5499-5509.

26 M. Strous, J. G. Kuenen and M. S. M. Jetten, Appl. Environ. Microbiol., 1999, 65, 3248-3250.

27 W. Chen, P. Westerhoff, J. a Leenheer and K. Booksh, Environ. Sci. Technol., 2003, 37, 5701-5710.

28 Y. Z. Lu, N. Li, Z. W. Ding, L. Fu, Y. N. Bai, G. P. Sheng and R. J. Zeng, Water Res., 2017, 122, 624-632.

29 G. Almendros and J. Dorado, Eur. J. Soil Sci., 1999, 50, 227236.

30 D. R. Lovley, J. D. Coates, E. L. Blunt-Harris, E. J. P. Phillips and J. C. Woodward, Nature, 1996, 382, 445-448. 